\title{
Descriptive Analysis of the Graphical Representations of Cycle-2 Primary Science Textbooks in Bahrain
}

\author{
${ }^{1}$ Faten S. M. Abdel-Hameed, ${ }^{2}$ Salah A.A. Emara \\ ${ }^{1}$ Bahrain Teachers College, University of Bahrain \\ ${ }^{2}$ Studies and Research Unit, University College of Bahrain
}

\begin{abstract}
Educational reform documents and research papers in the field emphasize the crucial role of analyzing the contents of science textbooks in improving science education. The broad objective of our critical review is to explore the effectiveness of Cycle-2 Primary Science textbooks and workbooks in terms of their reflection of the Bahrain Ministry of Education's school and curriculum reforms. The readability level, gender distribution, questioning cognitive levels and location, and graphical representations of concepts are examined. The purpose of this paper (part I of the review) is to quantify the type, quality and pedagogical functions of the graphical representations of the newly developed Cycle-2 primary science textbooks and the accompanying workbooks. Twelve Science textbooks and workbooks were examined using an authordeveloped graphical analysis grid. Descriptive statistical analysis was performed. Results show that the least analytic form of graphics dominated. There was an absence of maps and scale diagrams and most of the graphs were of static nature. Analysis also showed that indigenous graphics were dominant over foreign graphics. More than one third of the graphics served a specific cognitive function and were connected to the text, and most of them were captioned and indexed. Further research is undergoing to establish a connection between graphical representations and students, achievements and attitudes towards science.
\end{abstract}

\section{Introduction}

Science educators agree that textbooks play an important role in the teaching and learning processes [6], [7], [11]. Numerous research studies have been conducted on science textbooks analysis in the past several decades. Since textbooks are being used as a major source of information in teaching a particular subject, the quality and accuracy of the content is crucial for their educational effectiveness.

International organizations, such as the UNESCO formulated comprehensive strategies and guidelines on textbook research. In the UNESCO guidebook, Pingel [14] provided criteria for analyzing texts and modes of presentations; such as the use of illustrations, photos, maps, and tables and exercises.
The American Association for the Advancement of Science, (AAAS) Project 2061, developed an analysis protocols to evaluate the instructional effectiveness of science textbooks.

In analyzing the science textbooks researchers look into the balance between theoretical and practical knowledge, portrayal of minorities, women and gender fairness, treatment of socio-scientific and controversial issues, and depiction of graphical information, vocabulary load, comprehensibility and readability at intended level, accuracy and coherence, representation of indigenous knowledge, the role of textbook questions, dealing with misconceptions, and cultural and religious sensibility. A number of analytical tools have been constructed in recent years in the form of survey questionnaire, rubrics, grids, criteria, rating scheme and procedures using ethnographic content and reflexive document analyses, coding of the indicators, and image analysis protocols.

Slough et al [15] conducted a study to quantify the type and quality of the graphical representations and how they interacted with the textual material in middle school science texts in the United States. The team analyzed state approved sixth-grade science textbooks to determine the use of graphical representations in the books. They used purposely developed research instrument Graphical Analysis Protocol (GAP). The GAP was designed to identify and analyze the type and quality of the graphical representations and how they interacted with the textual material in the science texts. They reported that analytic forms of graphics were dominated in the text and one third of all graphics were decorative in nature, most graphics were static, and approximately one third were not connected to the text spatially or semantically and reasons for optimism.

In most cases, science textbooks originate in the western countries and they are adapted by others in different geographical regions and culture. Textbooks developed in western countries are primarily to serve their own education system and tend to carry western perspectives and culture (Aikenhead, [2]). Ninnes [13] stated the need to embrace indigenous knowledge and local culture of the society if we were to make these textbooks effective in their own contexts.

In Turkey, Irez [9] assessed five secondary school biology textbooks and examined the nature and the 
quality of treatment given to the nature of science. The author noted that there were serious problems with the way nature of science is portrayed in the textbooks. It was found that science was portrayed as collection of facts instead of a dynamic process of generating and testing alternative explanations about the nature.

In an attempt to determine the characteristics of the Nature of Science explained in the textbooks, Guisasola et al [8] examined 30 titles of university level Physics books that present the introduction of the concept and theories of magnetic field. They proposed that the textbooks can illustrate the characteristics of the Nature of Science by focusing on problems and change in the development of the theory of magnetic field.

Chiappetta and Fillman [5] analyzed the high school biology textbooks for inclusion of four aspects of the nature of science: (i) science as a body of knowledge, (ii) science as a way of investigating, (iii) science as a way of thinking, and (iv) science and its interactions with technology and society. They reported that the five recently published biology textbooks have a better balance of presenting biology with respect to the four themes of science literacy as compared to the textbooks that were used 15 years ago.

According to Lee [12], visual representations are commonly found in science textbooks and how they have been used is the focus of discussion among educators. The author examined the extent to which changes in representations in textbooks published in the US over the past six decades. It was found that high-fidelity images, such as photographs are more often used than the schematic and explanatory images to promote the familiarization to students.

Ajda Kahveci [10] quantitatively analyzed the effectiveness of Turkish chemistry and science textbooks. The author applied content analysis procedure to investigate gender equity, questioning level, science vocabulary load, and readability level and concluded that the textbooks included unfair gender representations, a considerably higher number of input-level and processing than output level questions, and high load of science terminology.

\section{Rationale and Purpose of the Study}

As part of the Bahrain Educational reform ourselves, we needed to perform this whole critical review of cycle-2 primary science textbooks and workbooks in order to reflect on how they are aligned with the principles and standards of the science curriculum reform and with the guiding principles of the Bahrain MOE education reform as a whole. This study is considered of a benefit to curriculum developers and teachers in producing reform-oriented science textbooks, which would help in improving the quality of science textbooks used in Bahrain.

Textbook quality has been correlated directly and indirectly to the success of education reforms and to the enhancement of students' understanding, Chambliss and Calfee [4]; Koppal and Caldwell [11]; Chiappetta and Fillman [5]; (Abd-El-Khalick et al., [1]). Well designed and written textbooks are shown to help students to understand the difficult concepts and overcoming scientific misconceptions. They are also expected to raise students' interests in learning science topics and eventually improve students' achievements in science.

The main objectives of the recently implemented MOE Educational and curriculum reform initiatives involve infusing constructivist principles, inquiry approach and higher order thinking skills to the teaching and learning of the science and mathematics, Bahrain Ministry of Education [3].

The following section will lay out the process of developing the science textbooks in Bahrain.

In this study, we utilize an authors' developed grid to quantitatively explore the type, function and quality of the graphical representations in cycle-2 primary science textbooks.

\section{Process of Developing Science Textbooks in Bahrain- Context of Study}

The Ministry of Education Science and Mathematics curriculum development was triggered by results of the Trends in International Mathematics and Science Studies (TIMSS). As several other countries, the Kingdom of Bahrain was unsatisfied with these results. This fueled the attempts to reform school Science and Mathematics curricula (Chiappetta \& Fillman, [5]).

A Science and Mathematics curriculum development team was formed. The team's job was to develop a new improved 1-12 Science and Mathematics curriculum that adopts inquiry and critical and creative thinking-based approaches. In order to make the new curricula work and bring all students to the level of understanding and skills proposed in the new Science curriculum, development included the content of textbooks, workbooks, teachers' instruction manuals as well as other learning and instructional materials.

The team started to examine various science and mathematics textbooks and accompanying materials from international publishing companies, looking for high quality learning materials in which the content addresses the ideas students are intended to learn, as described in the modified curriculum, and the instructional modes support effective teaching and student achievement of a learning goal. McGraw-Hill Science and Mathematics K-12 package was chosen.

A team of Science consultants and specialists performed, supervised and reviewed the adaptation 
and alignment of the Arabic versions of all learning materials with the Bahraini curriculum, with the aid of Obeikan publishing of Saudi Arabia.

Science: A Closer Look, from McGraw-Hill Science for primary 4,5 and 6 offers students' exciting and accessible standards-based lessons, engaging activities which promote curiosity and foster the development of science inquiry skills. Through a consistent and structured learning cycle (Engage, Explore, Explain, Evaluate and Elaborate), students confidently build upon their experiences to develop a lifelong understanding of science concepts in the following fields: Life sciences, Physical sciences, Earth sciences and Environmental sciences.

The adaptation and alignment of the McGraw-Hill Science learning materials followed a timeline. The first edition of cycle2 (primary 4, 5 and 6) science textbooks, workbooks, instruction manuals and other learning materials was published from 2009 to 2012 school years.

\section{Methodology}

\subsection{Sample}

The sample consisted of all Cycle 2 Science Students' Text-Books and Workbooks adopted in all government schools in the Kingdom of Bahrain that typically cover three years of instruction. Table 1 lists the titles that were covered in this study.

Table 1: List of textbooks under study

\begin{tabular}{|l|l|c|l|c|}
\hline No & Level & Part & \multicolumn{1}{|c|}{ Title } & Pages \\
\hline 1 & Primary 4 & I & Students' Text Book & 158 \\
\hline 2 & Primary 4 & I & Students' Work Book & 50 \\
\hline 3 & Primary 4 & II & Students' Text Book & 146 \\
\hline 4 & Primary 4 & II & Students' Work Book & 43 \\
\hline 5 & Primary 5 & I & Students' Text Book & 150 \\
\hline 6 & Primary 5 & I & Students' Work Book & 62 \\
\hline 7 & Primary 5 & II & Students' Text Book & 156 \\
\hline 8 & Primary 5 & II & Students' Work Book & 63 \\
\hline 9 & Primary 6 & I & Students' Text Book & 158 \\
\hline 10 & Primary 6 & I & Students' Work Book & 54 \\
\hline 11 & Primary 6 & II & Students' Text Book & 168 \\
\hline 12 & Primary 6 & II & Students' Work Book & 54 \\
\hline
\end{tabular}

\subsection{Research Tools}

All graphics in the selected books were coded and analyzed with the researchers' developed Graphical Analysis grid. We looked for the graphs' form, function, topic area, quality, ethnic representation, gender representation, type and relation to text. Table 2 lists the categories of graphics with clear descriptions.
Table 2: Graphic types with description

\begin{tabular}{|c|c|}
\hline \multicolumn{2}{|c|}{ Graph Type } \\
\hline \multicolumn{2}{|l|}{ I - Topic Area } \\
\hline Plant & $\begin{array}{l}\text { A plant photo or drawing of indigenous (local } \\
\text { Arabic -from the Gulf - or Bahraini) or foreign } \\
\text { origin (outside the Arabic world) }\end{array}$ \\
\hline Animal & $\begin{array}{l}\text { An animal photo or drawing of indigenous (local } \\
\text { Arabic -from the Gulf - or Bahraini) or foreign } \\
\text { origin (outside the Arabic world) }\end{array}$ \\
\hline Human & A human photo or drawing, female or male \\
\hline $\begin{array}{l}\text { Environmental } \\
\text { Science }\end{array}$ & $\begin{array}{l}\text { An environmental photo or drawing of indigenous } \\
\text { (local Arabic - from the Gulf - or Bahraini) or } \\
\text { foreign origin (outside the Arabic world) }\end{array}$ \\
\hline General & $\begin{array}{l}\text { A general-science photo or drawing of indigenous } \\
\text { (local Arabic -from the Gulf - or Bahraini) or } \\
\text { foreign origin (outside the Arabic world) }\end{array}$ \\
\hline Earth Science & $\begin{array}{l}\text { An earth science photo or drawing of indigenous } \\
\text { (local Arabic - from the Gulf - or Bahraini) or } \\
\text { foreign origin (outside the Arab world) }\end{array}$ \\
\hline $\begin{array}{l}\text { Physical } \\
\text { Science }\end{array}$ & $\begin{array}{l}\text { A chemistry or physics photo or drawing of } \\
\text { indigenous (local Arabic -from the Gulf - or } \\
\text { Bahraini) or foreign origin (outside the Arabic } \\
\text { world) }\end{array}$ \\
\hline \multicolumn{2}{|l|}{ II - Form } \\
\hline Photograph & Photograph only \\
\hline Drawing & All features are shown in details \\
\hline Map & $\begin{array}{l}\text { Geographical features with spatial relation to other } \\
\text { objects }\end{array}$ \\
\hline Table & Cells, rows and columns \\
\hline Flow chart & Arrows or numbers indicating stages \\
\hline Graph & Relationships, statistical bar or pie graphs,... \\
\hline \multicolumn{2}{|c|}{ III - Ethnic representation } \\
\hline Indigenous & Local photograph (gulf states or Arabic)or drawing \\
\hline Foreign & Non-local photograph or drawing \\
\hline \multicolumn{2}{|c|}{ IV - Gender representation } \\
\hline Female & Female human photograph or drawing \\
\hline Male & Male human photograph or drawing \\
\hline \multicolumn{2}{|l|}{ V- Indexing } \\
\hline None & Photograph or drawing is not mentioned in text \\
\hline indexed & Photograph or drawing is mentioned in text \\
\hline \multicolumn{2}{|l|}{ VI- Captioning } \\
\hline No caption & No title or description under graph or drawing \\
\hline captioned & $\begin{array}{l}\text { A title or description is written under graph or } \\
\text { drawing }\end{array}$ \\
\hline \multicolumn{2}{|l|}{ VII- Quality } \\
\hline Dynamic & $\begin{array}{l}\text { Use series of images to show change over time in } \\
\text { graph or drawing }\end{array}$ \\
\hline static & No change with time in graph or drawing \\
\hline \multicolumn{2}{|l|}{ VIII- Function } \\
\hline Decorative & $\begin{array}{l}\text { Does not support text, if taken out does not cause } \\
\text { any difference in understanding of the written text }\end{array}$ \\
\hline $\begin{array}{l}\text { Related to } \\
\text { Text }\end{array}$ & $\begin{array}{l}\text { Important to text written, if taken out will affect } \\
\text { understanding of text }\end{array}$ \\
\hline
\end{tabular}




\subsection{Analysis Procedures}

Following the development of the graphical analysis instrument, a coding key was used to establish a common understanding among the researchers. The data for each category were tabulated for each chapter in each textbook and workbook on a paper matrix. The data were then entered into an excel file and descriptive statistics for each variable were calculated.

The grid was validated by two science education specialists. In order to enhance the validity and reliability of the analysis procedure, two well experienced science curriculum specialists helped in performing the initial classification of the graphical representations, then the main author reviewed and re-entered the data into the excel grid for descriptive statistical calculations.

\section{Results and Data Interpretation}

In the following section, overall statistics regarding the number of pages and graphics analyzed, as well as results by research question according to the overall categories of: form, function, quality, ethnic representation and gender representation are reported for every grade level of cycle2's science texts and workbooks.

About 2,400 graphical representations were analyzed in the 12- textbooks and workbooks (two parts for every grade level). Illustrations covering all science topic areas were examined to answer the first research question in this study;

(1)What are the frequencies of the graphics among the science topic areas?

As shown in Table 3, for grade 4 students' text books: $42 \%$ of the graphics covered life sciences, followed by $19 \%$ for physical sciences, $16 \%$ for general sciences, $13 \%$ for environmental science and $3 \%$ for earth science. The largest percentage of graphics covered life sciences, as it is the most common topic area in this age and grade level. For grade 4 work books, life sciences graphics represented the highest percentages (36\%), followed by physical science $(28 \%)$, then general science $(25 \%)$ and environmental sciences $(1.5 \%)$, and earth sciences came last with a percentage of $(0.5 \%)$. For grade 5 students' text books, the same trend was found, as shown in Table 3, with 38\% of the graphics covering life sciences, $24 \%$ physical sciences, $18.5 \%$ general sciences, $13 \%$ environmental science and $6 \%$ earth sciences. For grade 5 work books, the trend was as follows: $36.5 \%$ of the graphics covered physical sciences, $28.5 \%$ general sciences, $28 \%$ life sciences, $4 \%$ environmental science and $3 \%$ earth sciences. Finally, for grade 6 students' text books: $40 \%$ of the graphics covered physical sciences, $32 \%$ life sciences, $14.5 \%$ general sciences, $10.5 \%$ environmental science and $2.5 \%$ earth sciences. For grade 6 work books: $45 \%$ of the graphics covered physical sciences, $20 \%$ life sciences, $20 \%$ general sciences, $10 \%$ environmental science and $3 \%$ earth sciences.

Table 3: Frequencies of graphics in various topic areas for Cycle-2 primary Science textbooks and workbooks

\begin{tabular}{|c|c|c|c|c|c|c|c|c|c|c|}
\hline \multirow{3}{*}{ Grade } & \multicolumn{10}{|c|}{ Topic Area } \\
\hline & \multicolumn{2}{|c|}{$\begin{array}{c}\text { Life } \\
\text { Sciences } \\
\text { (Plant + } \\
\text { Animal + } \\
\text { Human) }\end{array}$} & \multicolumn{2}{|c|}{$\begin{array}{l}\text { Physical } \\
\text { Sciences }\end{array}$} & \multicolumn{2}{|c|}{ Earth Sciences } & \multicolumn{2}{|c|}{$\begin{array}{l}\text { Environ } \\
\text { Science }\end{array}$} & \multicolumn{2}{|c|}{ General } \\
\hline & Freq & $\%$ & Freq & $\%$ & Freq & $\%$ & Freq & $\%$ & Freq & $\%$ \\
\hline $\begin{array}{c}4 \\
\text { textbook }\end{array}$ & 262 & 42 & 118 & 19 & 20 & 3 & 78 & 13 & 100 & 16 \\
\hline $\begin{array}{c}4 \\
\text { workbook }\end{array}$ & 72 & 36 & 56 & 28 & 1 & 0.5 & 3 & 1.5 & 50 & 25 \\
\hline $\begin{array}{c}5 \\
\text { textbook }\end{array}$ & 203 & 38 & 129 & 24 & 30 & 6 & 73 & 13 & 100 & 18.5 \\
\hline $\begin{array}{c}5 \\
\text { workbook }\end{array}$ & 49 & 28 & 64 & 36 & 5 & 3 & 7 & 4 & 50 & 28.5 \\
\hline $\begin{array}{c}6 \\
\text { textbook }\end{array}$ & 221 & 32 & 271 & 40 & 17 & 2.5 & 73 & 10.5 & 100 & 14.5 \\
\hline $\begin{array}{c}6 \\
\text { workbook }\end{array}$ & 45 & 20 & 100 & 45 & 0 & 0 & 0 & 0 & 76 & 34 \\
\hline Total & 852 & 36 & 738 & 31 & 73 & 3 & 234 & 10 & 476 & 20 \\
\hline
\end{tabular}

To answer the second research question:

(2)What is the distribution of the various forms of graphical representations?

The graphics in the 12 cycle- 2 primary textbooks and workbooks were examined and broken down to photographs, drawings, maps, tables, flow charts, graphs and hybrids, the results are shown in table 4 for grades 4, 5 and 6 textbooks, and in Table 5 for grades 4, 5, and 6 workbooks.

Results showed that: in grade 4 textbooks, both part I and II, photographs were the most common form of graphics at $96.5 \%$, while drawings came second at $2.8 \%$, hybrids at $0.5 \%$, tables at $0.3 \%$, flow charts at $0.2 \%$, maps at $0 \%$ and graphs at $0 \%$. In grade 4 work-books, both part I and II, photographs were the most common form of graphics at $95 \%$, with tables at $4 \%$, drawings at $1 \%$, maps at $0 \%$, flow charts at $0 \%$, graphs at $0 \%$ and hybrids at $0 \%$. In grade 5 textbooks, both part I and II, the same trend was observed, photographs were the most common form of graphics at $93 \%$, with drawings at $5 \%$, tables at $0.9 \%$, flow chart at $0.4 \%$, graphs at $0.2 \%$, 
maps at $0 \%$ and hybrids at $0.4 \%$. In grade 5 workbooks, both part I and II, photographs were the most common form of graphics at $93 \%$, with tables at $6 \%$, drawings at $0.5 \%$, flow charts at $0.5 \%$, maps at $0 \%$, graphs and hybrids at $0 \%$. In grade 6 textbooks, both part I and II, photographs were the most common form of graphics at $90 \%$, with drawings at $6 \%$, tables at $2 \%$, maps at $1 \%$, flow charts at $0.3 \%$, graphs at $0.3 \%$ and hybrids at $0.3 \%$. In grade 6 work-books, both part I and II, photographs were the most common form of graphics at $89.5 \%$, with drawings at $7.6 \%$, tables at $3 \%$, maps at $0 \%$, flow charts at $0 \%$, graphs at $0 \%$ and hybrids at $0 \%$.

Table 4: Distribution of the forms of graphical representations for grades: 4,5 and 6 textbooks

\begin{tabular}{|c|c|c|c|c|c|c|c|c|}
\hline \multirow{2}{*}{ Form } & \multicolumn{6}{|c|}{ Grade } & \multicolumn{2}{|c|}{ Total } \\
\cline { 2 - 8 } & \multicolumn{2}{|c|}{4} & \multicolumn{2}{|c|}{5} & \multicolumn{2}{|c|}{6} \\
\cline { 2 - 8 } & Fq & $\%$ & Freq & $\%$ & Freq & $\%$ & Freq & $\%$ \\
\hline Photograph & 578 & 96.5 & 511 & 93 & 640 & 90 & 1633 & 91.5 \\
\hline Drawing & 17 & 2.8 & 27 & 5 & 44 & 6 & 88 & 7 \\
\hline Table & 2 & 0.3 & 5 & 0.9 & 14 & 2 & 21 & 1.6 \\
\hline Map & 0 & 0 & 0 & 0 & 7 & 1 & 7 & 0 \\
\hline Flow chart & 1 & 0.2 & 2 & 0.4 & 2 & 0.3 & 5 & 0.3 \\
\hline Graph & 0 & 0 & 1 & 0.2 & 2 & 0.3 & 3 & 0.2 \\
\hline hybrid & 3 & 0.5 & 2 & 0.4 & 2 & 0.3 & 7 & 0.4 \\
\hline Total & 599 & 100 & 548 & 100 & 711 & 100 & 1764 & 100 \\
\hline
\end{tabular}

Table 5: Distribution of the forms of graphical representations for grades: 4,5 and 6 workbooks

\begin{tabular}{|c|c|c|c|c|c|c|c|c|}
\hline \multirow{2}{*}{ Form } & \multicolumn{6}{|c|}{ Grade } & \multicolumn{2}{|c|}{ Total } \\
\cline { 2 - 9 } & \multicolumn{2}{|c|}{$\mathbf{4}$} & \multicolumn{2}{|c|}{5} & \multicolumn{2}{|c|}{} \\
\cline { 2 - 9 } & Fq & $\%$ & Fq & $\%$ & Fq & $\%$ & Fq & $\%$ \\
\hline Photograph & 199 & 95 & 174 & 93 & 187 & 89.5 & 578 & 90 \\
\hline Drawing & 2 & 1 & 1 & 0.5 & 16 & 7.6 & 19 & 5 \\
\hline Table & 8 & 4 & 11 & 6 & 6 & 3 & 25 & 4.6 \\
\hline Map & 1 & 0.5 & 1 & 0.5 & 0 & 0 & 2 & 0.3 \\
\hline Flow chart & 0 & 0 & 0 & 0 & 0 & 0 & 0 & 0 \\
\hline Graph & 0 & 0 & 0 & 0 & 0 & 0 & 0 & 0 \\
\hline hybrid & 0 & 0 & 0 & 0 & 0 & 0 & 0 & 0 \\
\hline Total & 210 & 100 & 187 & 100 & 209 & 100 & 624 & 100 \\
\hline
\end{tabular}

The third question stated that:

(3) What is the distribution of the forms of graphical representations in the topic areas in the sampled primary science textbooks and work-books for cycle2?

Summaries of the distribution results for this research question are given in Tables 6 and 7 for cycle-2 textbooks and workbooks respectively, which show that photographs dominate all topic areas in all grade levels.

Table 6: Distribution of the forms of graphical representations in topic areas for grades 4, 5 and 6 textbooks:

(a) Grade 4 textbooks

\begin{tabular}{|c|c|c|c|c|c|c|c|c|c|c|c|c|}
\hline \multirow{3}{*}{ Form } & \multicolumn{12}{|c|}{ Grade 4} \\
\hline & \multicolumn{2}{|c|}{ Life Sciences } & \multicolumn{2}{|c|}{$\begin{array}{l}\text { Physical } \\
\text { Sciences }\end{array}$} & \multicolumn{2}{|c|}{$\begin{array}{c}\text { Earth } \\
\text { Sciences }\end{array}$} & \multicolumn{2}{|c|}{$\begin{array}{c}\text { Environment } \\
\text { al Science }\end{array}$} & \multicolumn{2}{|c|}{ General } & \multicolumn{2}{|c|}{ Total } \\
\hline & $\mathrm{Fq}$ & $\%$ & $\mathrm{Fq}$ & $\%$ & $\mathrm{Fq}$ & $\%$ & $\mathrm{Fq}$ & $\%$ & $\mathrm{Fq}$ & $\%$ & $\mathrm{Fq}$ & $\%$ \\
\hline Photogr & 254 & 97 & 110 & 93 & 20 & 100 & 78 & 100 & 96 & 96 & 587 & 97 \\
\hline Drawing & 8 & 3 & 8 & 7 & 0 & 0 & 0 & 0 & 4 & 4 & 17 & 3 \\
\hline Total & 262 & 100 & 118 & 100 & 20 & 100 & 78 & 100 & 100 & 100 & 604 & 100 \\
\hline
\end{tabular}

(b) Grade 5 textbooks

\begin{tabular}{|c|c|c|c|c|c|c|c|c|c|c|c|c|}
\hline \multirow{3}{*}{ Form } & \multicolumn{12}{|c|}{ Grade 5} \\
\hline & \multicolumn{2}{|c|}{ Life Sciences } & \multicolumn{2}{|c|}{$\begin{array}{l}\text { Physical } \\
\text { Sciences }\end{array}$} & \multicolumn{2}{|c|}{$\begin{array}{c}\text { Earth } \\
\text { Sciences }\end{array}$} & \multicolumn{2}{|c|}{$\begin{array}{l}\text { Environment } \\
\text { al Science }\end{array}$} & \multicolumn{2}{|c|}{ General } & \multicolumn{2}{|c|}{ Total } \\
\hline & Freq & $\%$ & Freq & $\%$ & Freq & $\%$ & Freq & $\%$ & Freq & $\%$ & Freq & $\%$ \\
\hline Photog & 187 & 92 & 126 & 98 & 27 & 90 & 68 & 93 & 98 & 98 & 511 & 95 \\
\hline Draw. & 16 & 8 & 3 & 2 & 3 & 10 & 5 & 7 & 2 & 2 & 27 & 5 \\
\hline Total & 203 & 100 & 129 & 100 & 30 & 100 & 73 & 100 & 100 & 100 & 538 & 100 \\
\hline
\end{tabular}

(c) Grade 6 textbooks

\begin{tabular}{|c|c|c|c|c|c|c|c|c|c|c|c|c|}
\hline \multirow{3}{*}{ Form } & \multicolumn{10}{|c|}{ Grade 6} \\
\cline { 2 - 14 } & \multicolumn{2}{|c|}{ Life Sciences } & \multicolumn{1}{|c|}{$\begin{array}{c}\text { Physical } \\
\text { Sciences }\end{array}$} & \multicolumn{2}{c|}{$\begin{array}{c}\text { Earth } \\
\text { Sciences }\end{array}$} & \multicolumn{2}{|c|}{$\begin{array}{c}\text { Environment } \\
\text { al Science }\end{array}$} & \multicolumn{2}{|c|}{ General } & \multicolumn{2}{|c|}{ Total } \\
\cline { 2 - 14 } & $\mathrm{Fq}$ & $\%$ & $\mathrm{Fq}$ & $\%$ & $\mathrm{Fq}$ & $\%$ & $\mathrm{Fq}$ & $\%$ & $\mathrm{Fq}$ & $\%$ & $\mathrm{Fq}$ & $\%$ \\
\hline Photog. & 196 & 89 & 255 & 94 & 36 & 100 & 67 & 92 & 96 & 96 & 659 & 94 \\
\hline Drawing & 25 & 11 & 16 & 6 & 0 & 0 & 6 & 8 & 4 & 4 & 44 & 6 \\
\hline Total & 221 & 100 & 271 & 100 & 36 & 100 & 73 & 100 & 100 & 100 & 703 & 100 \\
\hline
\end{tabular}

Table 7: Distribution of the forms of graphical representations in topic areas for grades 4,5 and 6 textbooks:

(a) Grade 4 workbooks

\begin{tabular}{|c|c|c|c|c|c|c|c|c|c|c|c|c|}
\hline \multirow{3}{*}{ Form } & \multicolumn{12}{|c|}{ Grade 4} \\
\hline & \multicolumn{2}{|c|}{ Life Sciences } & \multicolumn{2}{|c|}{$\begin{array}{l}\text { Physical } \\
\text { Sciences }\end{array}$} & \multicolumn{2}{|c|}{ Earth Sciences } & \multicolumn{2}{|c|}{$\begin{array}{l}\text { Environ } \\
\text { Science }\end{array}$} & \multicolumn{2}{|c|}{ General } & \multicolumn{2}{|c|}{ Total } \\
\hline & Freq & $\%$ & Freq & $\%$ & Freq & $\%$ & Freq & $\%$ & Freq & $\%$ & Freq & $\%$ \\
\hline Photog. & 70 & 97 & 50 & 90 & 1 & 100 & 3 & 100 & 47 & 94 & 171 & 94 \\
\hline Drawing & 2 & 3 & 6 & 10 & 0 & 0 & 0 & 0 & 3 & 6 & 11 & 6 \\
\hline $\begin{array}{l}\text { Total } \\
\end{array}$ & 72 & 100 & 56 & 100 & 1 & 100 & 3 & 100 & 50 & 100 & 182 & 100 \\
\hline
\end{tabular}


(b) Grade 5 work-books

\begin{tabular}{|c|c|c|c|c|c|c|c|c|c|c|c|c|}
\hline \multirow{3}{*}{ Form } & \multicolumn{12}{|c|}{ Grade 5} \\
\hline & \multicolumn{2}{|c|}{ Life Sciences } & \multicolumn{2}{|c|}{$\begin{array}{l}\text { Physical } \\
\text { Sciences }\end{array}$} & \multicolumn{2}{|c|}{$\begin{array}{c}\text { Earth } \\
\text { Sciences }\end{array}$} & \multicolumn{2}{|c|}{$\begin{array}{c}\text { Environm } \\
\text { Science }\end{array}$} & \multicolumn{2}{|c|}{ General } & \multicolumn{2}{|c|}{ Total } \\
\hline & $\mathrm{Fq}$ & $\%$ & $\mathrm{Fq}$ & $\%$ & $\mathrm{Fq}$ & $\%$ & $\mathrm{Fq}$ & $\%$ & $\mathrm{Fq}$ & $\%$ & $\mathrm{Fq}$ & $\%$ \\
\hline Photog. & 49 & 100 & 60 & 94 & 5 & 0 & 7 & 100 & 47 & 94 & 168 & 96 \\
\hline Draw & 0 & 0 & 4 & 6 & 0 & 0 & 0 & 0 & 3 & 6 & 7 & 4 \\
\hline Total & 49 & 100 & 64 & 100 & 5 & 0 & 7 & 100 & 50 & 100 & 175 & 100 \\
\hline
\end{tabular}

(c) Grade 3 work-books

\begin{tabular}{|c|c|c|c|c|c|c|c|c|c|c|c|c|}
\hline \multirow{3}{*}{ Form } & \multicolumn{12}{|c|}{ Grade 6} \\
\hline & \multicolumn{2}{|c|}{ Life Sciences } & \multicolumn{2}{|c|}{$\begin{array}{l}\text { Physical } \\
\text { Sciences }\end{array}$} & \multicolumn{2}{|c|}{$\begin{array}{c}\text { Earth } \\
\text { Sciences }\end{array}$} & \multicolumn{2}{|c|}{$\begin{array}{c}\text { Environm } \\
\text { Science }\end{array}$} & \multicolumn{2}{|c|}{ General } & \multicolumn{2}{|c|}{$\begin{array}{l}\text { Total } \\
\end{array}$} \\
\hline & $\mathrm{Fq}$ & $\%$ & $\mathrm{Fq}$ & $\%$ & $\mathrm{Fq}$ & $\%$ & $\mathrm{Fq}$ & $\%$ & $\mathrm{Fq}$ & $\%$ & $\mathrm{Fq}$ & $\%$ \\
\hline Photog. & 31 & 69 & 85 & 85 & 0 & 0 & 0 & 0 & 74 & 97 & 195 & 93 \\
\hline Draw. & 14 & 31 & 15 & 15 & 0 & 0 & 0 & 0 & 2 & 3 & 16 & 7.5 \\
\hline $\begin{array}{l}\text { Total } \\
\end{array}$ & 35 & 100 & 100 & 100 & 0 & 0 & 0 & 0 & 76 & 100 & 221 & 100 \\
\hline
\end{tabular}

The fourth question deals with the gender representations:

(4) What is the distribution of the gender representations of graphics in the sampled primary science textbooks and work-books for cycle2?

The answer to the above question is summarized in Table 8, which shows that male representations dominated both photographs $(70 \%$ of grade 4 textbooks, $83 \%$ of grade 4 workbooks, $82 \%$ of grade 5 textbooks, $50 \%$ of grade 5 workbooks, $82 \%$ of grade 6 textbooks and $64 \%$ of grade 6 workbooks) and drawings ( $10 \%$ of all grade levels).

Table 8: Distribution of the gender representations of graphics for grades 4,5 and 6 textbooks and work-books

\begin{tabular}{|c|c|c|c|c|}
\hline \multirow{2}{*}{ Grade } & \multicolumn{4}{|c|}{ Gender } \\
\cline { 2 - 5 } & \multicolumn{2}{|c|}{ Photograph } & \multicolumn{2}{c|}{ Drawing } \\
\cline { 2 - 5 } & $\mathrm{M}^{*}$ & $\mathrm{~F}^{* *}$ & $\mathrm{M}^{*}$ & $\mathrm{~F}^{* *}$ \\
\hline 4 (textbook) & 72 & 24 & 1 & 0 \\
\hline 5 (textbook) & 59 & 12 & 1 & 0 \\
\hline 6 (textbook) & 107 & 24 & 1 & 0 \\
\hline 4 (workbook) & 9 & 9 & 1 & 0 \\
\hline 5 (workbook) & 23 & 5 & 1 & 0 \\
\hline 6 (workbook) & 29 & 16 & 1 & 0 \\
\hline
\end{tabular}

$* \mathrm{M}=$ Male, ${ }^{*} * \mathrm{~F}=$ Female

Question 5 stated that:

(5) What was the ethnic representation (indigenous, foreign) of the graphics in the newly developed cycle-2 primary science textbooks and workbooks?

Ethnic representation data for both research questions are given in tables 9 and 10 for cycle- 2 primary science textbooks and workbooks, respectively. We can see that the indigenous graphics dominated all grade levels in all topics, making $60 \%$ of the photographs and $72 \%$ of the drawings.

Table 9: Distribution of ethnic representations in Grades 4, 5 and 6 textbooks

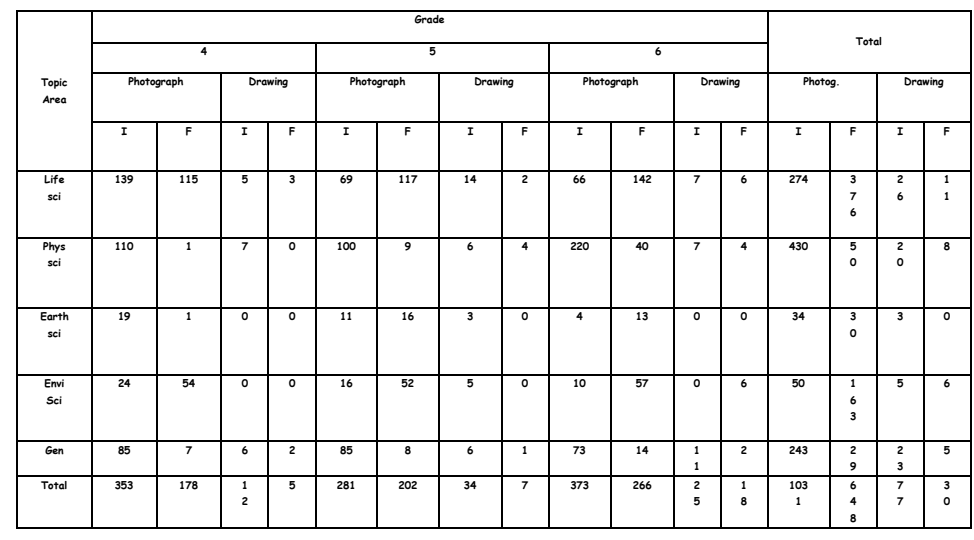

Table 10: Distribution of ethnic representations in Grades 4, 5 and 6 workbooks (I= Indigenous, F = Foreign)

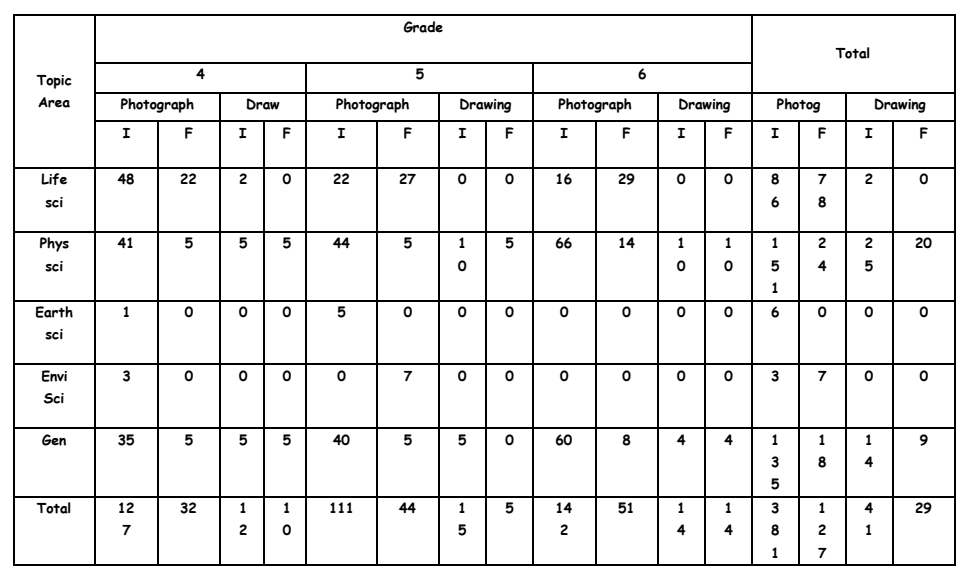

The sixth research question stated that:

(6)What were the functions (decorative- doesn't support text, representational-illustrating a concept, organizational-places text within a greater scheme e.g. scale diagram, related to text) of the graphical representations in the newly developed cycle-2 primary science textbooks and workbooks?

The answer to that question is clear from table 11 and table 12, which show that the majority of the graphics were decorative in nature, while a small percentage were representational and organizational (related to text). It can also be seen from Tables 11 and 12 that the number of representational and organizational graphics increases as we go to higher grades. 
Table 11: Distribution of the functions of graphical representations for grades: 4, 5 and 6 textbooks

\begin{tabular}{|c|c|c|c|c|c|c|c|c|}
\hline \multirow{3}{*}{ Function } & \multicolumn{6}{|c|}{ Grade } & \multirow{2}{*}{\multicolumn{2}{|c|}{ Total }} \\
\hline & \multicolumn{2}{|c|}{4} & \multicolumn{2}{|c|}{5} & \multicolumn{2}{|c|}{6} & & \\
\hline & Freq & $\%$ & Freq & $\%$ & Freq & $\%$ & Freq & $\%$ \\
\hline Decorative & 510 & 82 & 402 & 75 & 481 & 70 & 1393 & 76 \\
\hline $\begin{array}{l}\text { Representa- } \\
\text { tional }\end{array}$ & 61 & 10 & 82 & 15 & 114 & 16 & 257 & 14 \\
\hline $\begin{array}{c}\text { Organization } \\
\text { al }\end{array}$ & 51 & 8 & 54 & 10 & 89 & 13 & 194 & 10 \\
\hline Total & 622 & 100 & 538 & 100 & 684 & 100 & 1844 & 100 \\
\hline
\end{tabular}

Table 12: Distribution of the functions of graphical representations for grades: 4,5 and 6 workbooks

\begin{tabular}{|c|c|c|c|c|c|c|c|c|}
\hline \multirow{3}{*}{ Function } & \multicolumn{6}{|c|}{ Grade } & \multirow{2}{*}{\multicolumn{2}{|c|}{ Total }} \\
\hline & \multicolumn{2}{|c|}{4} & \multicolumn{2}{|c|}{5} & \multicolumn{2}{|c|}{6} & & \\
\hline & Freq & $\%$ & Freq & $\%$ & $\begin{array}{c}\text { Fre } \\
\text { q }\end{array}$ & $\%$ & Freq & $\%$ \\
\hline Decorative & 139 & 69 & 105 & 60 & 121 & 55 & 365 & 61 \\
\hline $\begin{array}{l}\text { Representa- } \\
\text { tional }\end{array}$ & 35 & 17 & 38 & 22 & 67 & 30 & 140 & 23 \\
\hline Organizational & 27 & 14 & 32 & 18 & 33 & 15 & 92 & 16 \\
\hline Total & 201 & 100 & 175 & 100 & 221 & 100 & 597 & 100 \\
\hline
\end{tabular}

\section{Regarding questions 7 ,}

(7)What was the quality (dynamic, static) of the graphical representations in the newly developed cycle-2 primary science textbooks and workbooks?

As shown in Tables 13 and 14, the static graphics dominated in all grade levels and topic areas, with more in the lower grade levels.

Table 13: Distribution of the quality of graphical representations for grades: 4,5 and 6 textbooks

\begin{tabular}{|c|c|c|c|c|c|c|c|c|}
\hline \multirow{3}{*}{ Quality } & \multicolumn{6}{|c|}{ Grade } & \multirow{2}{*}{\multicolumn{2}{|c|}{ Total }} \\
\hline & \multicolumn{2}{|c|}{4} & \multicolumn{2}{|c|}{5} & \multicolumn{2}{|c|}{6} & & \\
\hline & Freq & $\%$ & Freq & $\%$ & Freq & $\%$ & Freq & $\%$ \\
\hline Static & 502 & 81 & 411 & 76 & 494 & 72 & 1407 & 76 \\
\hline Dynamic & 120 & 19 & 127 & 24 & 190 & 28 & 437 & 24 \\
\hline Total & 622 & 100 & 538 & 100 & 684 & 100 & 1844 & 100 \\
\hline
\end{tabular}

Table 14: Distribution of the quality of graphical representations for grades: 4, 5 and 6 workbooks

\begin{tabular}{|c|c|c|c|c|c|c|c|c|}
\hline \multirow{3}{*}{ Quality } & \multicolumn{6}{|c|}{ Grade } & \multirow{2}{*}{\multicolumn{2}{|c|}{ Total }} \\
\hline & \multicolumn{2}{|c|}{4} & \multicolumn{2}{|c|}{5} & \multicolumn{2}{|c|}{6} & & \\
\hline & Freq & $\%$ & Freq & $\%$ & $\begin{array}{c}\text { Fre } \\
\text { q }\end{array}$ & $\%$ & Freq & $\%$ \\
\hline Static & 171 & 85 & 138 & 79 & 167 & 76 & 476 & 82 \\
\hline Dynamic & 30 & 15 & 37 & 21 & 54 & 24 & 121 & 18 \\
\hline Total & 201 & 100 & 175 & 100 & 221 & 100 & 597 & 100 \\
\hline
\end{tabular}

The last research question in this study dealt with the indexing and captioning of the graphics in various grade levels;

(8)What was the connection of the graphics, in the newly developed cycle-2 primary science textbooks and workbooks, to the written text (indexing, captioning)?

Tables 15 and 16, show the data regarding the connection of the graphics to the written text (indexing, captioning) in the newly developed cycle2 primary science textbooks and workbooks, respectively. We can see that, $88 \%$ of the graphics are captioned and $95 \%$ of them are indexed.

Table 15: Distribution of the indexing and captioning of graphics in grades 4,5 and 6 cycle- 2 primary science textbooks

\begin{tabular}{|c|c|c|c|c|c|c|c|c|}
\hline \multirow{3}{*}{$\begin{array}{c}\text { Indexing and } \\
\text { Captioning }\end{array}$} & \multicolumn{6}{|c|}{ Grade } & \multirow{2}{*}{\multicolumn{2}{|c|}{ Total }} \\
\hline & \multicolumn{2}{|l|}{4} & \multicolumn{2}{|l|}{5} & \multicolumn{2}{|l|}{6} & & \\
\hline & Frequency & $\%$ & Frequency & $\%$ & Frequency & $\%$ & Frequency & $\%$ \\
\hline Indexed & 525 & 84 & 485 & 9 & 597 & 87 & 1607 & 87 \\
\hline Not-indexed & 97 & 16 & 53 & 1 & 87 & 13 & 237 & 13 \\
\hline Captioned & 591 & 95 & 508 & 9 & 618 & 90 & 1717 & 93 \\
\hline Not-captioned & 31 & 5 & 30 & 6 & 66 & 10 & 127 & 7 \\
\hline
\end{tabular}

Table 16: Distribution of the indexing and captioning of graphics in grades 4,5 and 6 cycle- 2 primary science workbooks

\begin{tabular}{|c|c|c|c|c|c|c|c|c|}
\hline \multirow{3}{*}{$\begin{array}{l}\text { Indexing and } \\
\text { Captioning }\end{array}$} & \multicolumn{6}{|c|}{ Grade } & \multirow{2}{*}{\multicolumn{2}{|c|}{ Total }} \\
\hline & \multicolumn{2}{|l|}{4} & \multicolumn{2}{|l|}{5} & \multicolumn{2}{|l|}{6} & & \\
\hline & Frequency & $\%$ & Frequency & $\%$ & Frequency & $\%$ & Frequency & $\%$ \\
\hline Indexed & 181 & 90 & 154 & 8 & 198 & 89 & 533 & 89 \\
\hline Not-indexed & 20 & 10 & 21 & $\begin{array}{l}1 \\
2\end{array}$ & 23 & 11 & 64 & 11 \\
\hline Captioned & 192 & 95 & 168 & $\begin{array}{l}9 \\
6\end{array}$ & 213 & 96 & 573 & 96 \\
\hline Not-captioned & 9 & 5 & 7 & 4 & 8 & 4 & 24 & 4 \\
\hline
\end{tabular}




\section{Discussion and Further Research}

In this study, a descriptive statistical analysis of the type, function and quality of the graphical representations in 12-Bahrain cycle-2 primary science textbooks and workbooks was performed. The results of this study suggest that all graphic forms were represented. Most forms of graphics are represented across all from topic areas. About 70\% of graphical representations are general, $36 \%$ belong to life science topic area, $10 \%$ to environmental science, $3 \%$ to earth science and $31 \%$ to physical science. Results also showed that less than one third of the graphics were of the more analytic forms; more than one third served a specific cognitive purpose; $39 \%$ were well connected to the text; $87 \%$ were indexically referenced. Two third of the graphics were decorative; $76 \%$ were static representations; $13 \%$ were not indexically referenced; and 7\% did not have captions.

This summation shows that graphics were primarily added to the text to make it more appealing to the teachers and students. There was an absence of maps and scale diagrams. Analysis also showed that indigenous graphics represented about $65 \%$ while foreign graphics represented $35 \%$ of the total graphics. Male representations made $77 \%$ of the graphics, while female ones made $23 \%$ of them. Future work is underway, taking into account the gender equity issues, the readability level, the questioning levels and the scientific vocabulary loads. Research is being performed in order to examine the connection between graphical representations and students' achievements and attitudes toward science.

\section{References}

[1] Abd-El-Khalick, F., Boujaoude, S., Duschl, R., Lederman, N. G., Mamlok-Naaman, R., Hofstein, A., et al. (2004). Inquiry in science education: International perspectives. Science Education, 88, 397-419.

[2] Aikenhead, G.S. (1997). Towards a First Nations crosscultural science and technology curriculum. Science Education, 81, 217-238.

[3] Bahrain Ministry of Education (2013): Accessed on April 16, 2013 at:http://www.moe.gov.bh/projects.aspx

[4] Chambliss, M. J. and Calfee, R. C. (1989). Designing science textbooks to enhance students' understanding.Educational Psychologist, 24(3), 307-322.

[5] Chiappetta, E., \& Fillman, D. (2007). Analysis of five high school biology textbooks used in the United States for inclusion of the Nature of Science. International Journal of Science Education, 29 (15), 1847-1868.
[6] Clement, P. (2008). Critical analysis of school science textbooks. Science Education International, 19(2), 93-96.

[7] Graham, C. (1941). Some data pertaining to textbooks of general science. Science Education, 25 (1), 35-41.

[8] Guisasola, J., Almudi, J., \& Furio, C. (2005). Thenature of science and its implications for physics textbooks. Science \& Education, 14, 321-338.

[9] Irez, S. (2008). Nature of science as depicted in Turkish biology textbooks. Science Education, 93 (3), 422447.

[10] Kahveci, A. (2010). Quantitative Analysis of Science and Chemistry Textbooks for Indicators of Reform: A complementary perspective. International Journal of Science Education, 32 (11), 1495-1519.

[11] Koppal, M., \& Caldwell, A. (2004). Meeting the challenge of science literacy: Project 2061 efforts to improve science education. Cell Biology Education, 3 (1), 28-30.

[12] Lee, V. R. (2010). Adaptation and continuities in the use and design of visual representations in US middle school science textbooks. International Journal of Science Education, 32 (8), 1099-1126.

[13] Ninnes, P. (2000). Representations of indigenous knowledge in secondary school science textbooks in Australia and Canada. International Journal of Science Education, 22 (6), 603-617.

[14] Pingel, F. (2010). UNESCO Guidebook on Textbook Research and Textbook Revision. Paris: United Nations Educational, Scientific and Cultural Organization.

[15] Slough, S., McTigue, E., Kim, S \& Jennings, S. (2010). Science textbooks' use of graphical representations: A descriptive study of four sixth grade science texts. Reading Psychology, 31, 301-325. 